\title{
Kırılganlıktan Kapasite Geliştirmeye
}

\author{
Nilgün Okay ${ }^{1 *}$ ve Ebru İnal ${ }^{2}$
}

\section{Öz}

Afet risk azaltma planlanması ve stratejilerinin uygulanmasında halkın tümünün paydaş olarak yer aldığı yaklaşımların afete dirençliliği geliştirmede başarılı olduğu bilinmektedir. Afete dirençlilik bakımından toplumun tüm kesimlerinin görüşlerini sağlayan, bireylerin kapasitelerini geliştiren, çözümün ve uygulamanın parçası haline gelmesini sağlayan katıımcı yaklaşımlar öncelikli olmalıdır. Halbuki afet risk azaltma süreçlerinde, sadece teknik uzmanların karar verdiği planlama yaklaşımı hakimdir. Engelli veya özel gereksinimli bireylerin zarargörebilirlikleri (kırılganlıkları) ve intiyaçlarından söz edilmekte, fakat kapasite ve yetenekleri göz önüne alınmamaktadır. Temel hak ve özgürlükler bakımından bu bireyler sosyal hayatın içinde olmak istemelerine rağmen, hem fiziksel hem de sosyal engeller nedeniyle kırılganlıkları daha da artmaktadır. Başta aileler olmak üzere tüm toplum özel gereksinimli bireylerin kapasiteleri ve yapabilecekleri konusunda bilinçlenmelidir. Özel gereksinimli bireylerin sosyal yaşama dahil olması, görünür hale gelmesi, meslek edinmesi, afete hazırlık kapasitelerinin geliştirilmesi, farkındalığının arttıııması ve katıımcı planlama yaklaşımı kullanarak duyarlı afet risk yönetiminin geliştirilmesi toplumsal dirençlilik sağlanacaktır. Bu bağlamda, duyarlı ulusal afet risk azaltma stratejilerinin geliştirilebilmesi için çoklu-özel gereksinimlilik verisinin oluşturulması ve konuda araştırma çalışmalarının da desteklenmesi önemlidir.

Anahtar Kelimeler: afet risk azaltma, çoklu-gereksinimlilik, dirençlilik, kapasite, katılımcı planlama, zarargörebilirlik

\section{From Vulnerability to Capacity Building}

\begin{abstract}
\footnotetext{
${ }^{1}$ İstanbul Teknik Üniversitesi, Jeoloji Müh Bölümü ve Afet Yönetimi Merkezi

${ }^{2}$ Çanakkale Onsekiz Mart Üniversitesi, Acil Yardım ve Afet Yönetimi

*ilgili yazar / Corresponding author: okayn@itu.edu.tr

Gönderim Tarihi: 26.05.2019

Kabul Tarihi: 29.06.2019
}

It is known that approaches that involve all stakeholders in disaster risk reduction planning and implementation of strategies are successful in developing disaster resilience. Participatory approaches that provide the views of all segments of the society, improve the capacities of individuals, and become part of the solution and implementation should be a priority. However, disaster planning mitigation processes are predominantly based on the planning approach decided by technical experts. The vulnerability and needs of individuals with disabilities or special needs are addressed, but their capacity and capabilities are not considered. Although these individuals want to be in social life in terms of fundamental rights and freedoms, their vulnerability increases even more due to both physical and social barriers. The whole society, especially the families, should be made aware of the capacities and capabilities of individuals with special needs. Social resilience will be ensured by

Bu makaleye atıf yapmak için- To cite this article Okay, N., \& İnal, E. (2019). Kırılganlıktan Kapasite Geliştirmeye. Resilience, 3(1), 85-99. 
involving individuals with special needs, making them visible, acquiring a profession, developing disaster preparedness capacities, raising awareness and developing sensitive disaster risk management by using participatory planning approach. In this context, in order to develop sensitive national disaster risk mitigation strategies, it is important to create multispecial needs data and to support research studies on the assessment.

Keywords: capacity, disaster risk reduction, participatory planning, resilience, vulnerability,

\section{GíRiş}

Yaşanan afetlerde, özel gereksinimli bireylerin zarar görebilme olasılığının çok daha fazla olduğu, hayatını kaybedenlerin sayısının dört kat daha fazla olduğu araştırmalarla ortaya konulmaktadır (Arnold ve diğ. 2018). Yapılan araştırmalarda risk grupları adı altında bulunan bireylerin yetersizlikleri, farklılıkları ele alınmakta, gereken intiyaçları incelenmektedir. Halkın tümünün afetlere hazır olması, afet risk azaltma çalışmalarında yer almasının büyük kazanımlar sağladığı görülmesine rağmen, özel gereksinimli bireyler riskli ve kııılgan gruplar olarak kabul edilmekte ve hala afet risk azaltma planlarına dâhil edilmesi ve katılımı göz ardı edilmektedir.

\section{1. Özel Gereksinimliliğin Yaygınlığı ve Artışı}

Dünyada bir milyardan fazla insan herhangi bir tür gereksinimlilik ile yaşamaktadır (Kırıkkaya ve Gerdan 2018). Bu insanların yaklaşık 200 milyonu hayatlarını devam ettirme konusunda çeşitli engellerle karşılaşmakta ve zorluklar yaşamaktadır. Nüfusumuzun yaklaşık \%15'ini sadece bedensel, görme, işitme, konuşma ve öğrenme gibi farklı gereksinimlere sahip bireylerin oluşturduğu verisi TÜİK (2015 ve 2017) tarafından bildirilmektedir. Ülkemizde her yıl binlerce çocuk işitme kaybı veya gelişim bozukluğu ile doğarken bireyler çeşitli nedenlerle yaşamını gereksinimli olarak sürdürmektedir. Sayısı hızla artan tahmini 550 bin civarında otizmli birey yaşamakta ve bu durumun aileleriyle birlikte 2 milyon kişinin hayatını etkilediği belirtilmektedir (Otsimo 2018). Ayrıca ruhsal, ortopedik ve kronik hastalıklar nedeniyle bireyler farklı gereksinimlilik durumu yaşamaktadır.

Nüfusun yaşlanıyor olması durumu tüm dünyada gündem konusudur. Türkiye Sağlık Araştırması Raporu'na göre Türkiye'de nüfusun sadece yaklaşık \%10'unun yürümekte ve hatta merdivenden inip çıkmakta zorlandığı belirtilmektedir (TÜIK 2016). Yaşlı insanlarda gereksinimlilik oranının yüksek olması, ilgili kronik sorunlar ile demans, alzheimer gibi yeni riskleri beraberinde getirmesi, gereksinimli bireylerin sayısını ve dünya genelinde yaygınlığını da arttırmaktadır. Ülkemizde de 2030 yılında yaşı nüfusun toplam nüfus içindeki düzeyinin \%14'ü bulacağı tahmin edilmektedir. Eşi ölmüş yaşı kadınların düzeyi ise \%50,4 olmuş durumdadır. Yalnız yaşayan yaşlı nüfusun \%76,7'sini ise kadınlar oluşturmaktadır (TÜIK 2017; Aile ve Sosyal Politikalar Bakanlığı 2018).

$\mathrm{Bu}$ durumda gereksinimlilik yaygınlaşırken karmaşıkı̆̆ı da artmaktadır. Sağlık sorunları, kişisel ve çevresel etkiler tekdüze değil, çeşitlilik göstermektedir. Bu yüzden gereksinimli bireylerin hepsi eşit derecede kırılgan değildir veya gereksinimliliğe bağlı olarak kırılganlık da değişmektedir. Örneğin engelli kadınlar kısıtlayan faktörlerin yansıra toplumsal cinsiyet ayrımcılığına da maruz kalmaktadır (Okay ve İlkkaracan 2018). Önümüzdeki yıllarda beklenen durum, nüfusun birden fazla gereksinimlilik içereceği, yani çoklu-gereksinimliliğe sahip olacağıdır.

\section{2. Özel Gereksinimlilik ve Engelleyen Faktörler}

Özel gereksinimli bireyler, gündelik toplumsal yaşama katılımda çeşitli problemlerle karşı karşıyadır (Çaha 2013). Gereksinimlilik, genel olarak bireyin fiziksel yetersizliğine, 
patolojisine yani hastalık durumuna göre, tıbbi olarak açıklanmaktadır (Arıkan 2002). Bu yüzden özel gereksinimli bireyler sağlık ve çeşitli fiziksel yetersizliklerinden dolayı toplum tarafından ayrı bir grup olarak algılanmaktadır. Bunun yanı sıra gereksinimli bireylerin gündelik yaşama katıımında dış etkiler zorluk ve engelleri oluşturmaktadır. Gereksinimli bireylerin toplum hayatında görünürlüğüne etki eden bu faktörlerin en başında hizmetlere ulaşılabilirliğin sağlanamaması veya yetersizliği gelmektedir. Özellikle sağlık, sosyalgüvenlik, eğitim hizmetlerindeki yetersizlikler karşısında düşük gelirli bireyler daha fazla kırılgandır. Gelişmiş ülkelerde bile en yüksek yoksulluk riskine sahip olanlar gereksinimli bireylerdir. Sosyal yaşama katılımda etkili olan sosyal politika ve standartlar farklı gereksinimleri göz önünde bulundurmamaktadır. Mevcut uygulamalara ayrılan maddi, insan ve teknik kaynaklar da yetersiz kalmaktadır. Örneğin, çalışan personelin özel gereksinimli bireylere yönelik farkındalıklarının ve ilgili niteliklerinin yetersiz olması da hizmet ulaşıllabilirliğ ini önemli ölçüde etkilemektedir.

Özel gereksinimli bireylerin sosyal yaşama dahil olmasını sağlayan dış etkilerin başında mimari ulaşılabilirlik veya erişilebilirlik gelmektedir. Kentsel mekânlar (kamusal kullanıma açık alanlar ve binalar), kentsel ulaşım sistemi herkes için erişilebilir olmalıdır. Özel gereksinimli bir bireyin evden rahatıkla çıkmasının yansıra, eğitim ve sağlık hizmetlerinden yararlanması temel hakkıdır. Ülkemizde mimari erişilebilirliği sağlayacak kapsayıcı evrensel tasarım uygulamalarına yeni başlanmış, henüz yaygınlaşmamıştır (Aile ve Sosyal Politikalar Bakanlığı 2017). Ulaşım erişilebilirliği toplumsal hayata katılımı sağlayan öncelikli bir konudur. AB'ye uyum çerçevesinde toplu taşıma hizmetlerinin gereksinimli bireylerin kullanımına uygun hâle getirilmesine başlanmıştır. Örneğin, Engelli Durak Bilgilendirme Sistemi, Akıllı Durak İşitme Sistemi gibi projelere rağmen henüz belediye otobüslerinin tamamı özel gereksinimli kullanımına hazır değildir. İstanbul'da metro ve metrobüs duraklarının sadece küçük bir kısmında (28 istasyon) düzenlemeler yapılmıştır (Trafik Haber 2010; Engelliler Biz Platformu 2009).

Hizmet ulaşılabilirliği sorunlarının başında özel gereksinimli bireylerin bilgi edinme, eğitime erişilebilirliği ve meslek edinme imkânlarının kısıtlı olması gelmektedir. Ülkemizde özel gereksinimli çocuk ve gençlerin sadece \% 15'i okula gidebilmekte, eğitim hizmetlerinden yararlanabilmektedir. Örneğin işitme engellilere yönelik 50, görme engellilere yönelik 20 okul bulunmaktadır (Engelsiz erişim 2018). Türkiye Sağlık Araştırması (2016) verilerine göre gereksinimlilik 75 yaş üzeri kadınlarda (\%50) artarken, bu nüfusun \%31'i okur-yazar değildir (TÜIK 2011).

Özel gereksinimli bireyler hakkında yaygın olarak yerleşmiş önyargılar, toplumsal yaşama katılımda sosyal engeller oluşturmaktadır (Aslan ve Şeker 2011). Başbakanlık Özürlüler İdaresi Başkanlığı (yeni adıyla Aile ve Sosyal Politikalar Bakanlığına bağı Engelli ve Yaş/ı Hizmetleri Genel Müdürlügü) tarafından gerçekleştirilen Toplumda Özürlülük Algısı araştırmasına göre özel gereksinimli bireyler yardıma muhtaç kişi olarak tanımlanmaktadır (Özida projesi 2010). Ayrımcılığı Önleme Platformunun Engelli Konumlandırma Araştırmasında özel gereksinimli bireyler ile aynı iş yerinde çalışmak ve özellikle de zihinsel engelliler ile arkadaş olmak istemeyenlerin oranı oldukça yüksektir (Hürriyet 2012). Örneğin, Sosyal Hizmetler ve Çocuk Esirgeme Kurumunda müdür olarak çalışan bir özel gereksinimli birey, personelin kendisiyle çalışmak istemediğini ve kendisinden emir almaktan rahatsızlık duyduğunu belirtmiştir (DBP 2018).

$\mathrm{Bu}$ toplumsal algılar ayırımcı tutumlara, sosyal baskı ve olumsuz değerlendirmelere yol açmakta, özel gereksinimli bireylerin kırılganlıklarını daha da artırmaktadır (Kumtepe 2002; Arıkan 2002; Çaha 2016). Bireyin kendi hakkında karar vermek istemesi ve intiyaç duymasına rağmen, gereksinimli oluşu nedeniyle yetersiz olarak tanımlanmakta ve 
düzenlemeler yapılmaktadır. Bu geleneksel yaklaşım bireyleri daha da engellenmiş hissetmelerine, daha da kırılgan duruma itilmelerine neden olmaktadır.

Yasal mevzuatta düzenleme ve gerçekleştirilen değişikliklerle son yıllarda engellilere yönelik ayrımcılığın azaldığı tahmin edilmektedir (Murat 2009). Bu konuda en etkili çalışma gereksinimli bireylerin işgücüne katıımını kolaylaştıracak düzenleme ve teşvik verilmesi olmuştur. İstihdama yönelik stratejik çalışmaların oluşturulması, geliştirilmesi ve uygulanmasında, örneğin, yasayla getirilen istihdam yükümlülüğünün sağlanmasında henüz çeşitli sorunlar bulunmaktadır. Bu çalışmalara temel teşkil edecek istatistikî verilerin toplanmasına da çok geç başlandığı görülmektedir (Çaha 2016; TÜİK 2016; Aile ve Sosyal Politikalar Bakanlığı 2017, 2018). Gereksinimli bireylerin ekonomik hayata katılımı henüz başlangıç aşamasındadır. Kamuda işçi olarak çalışan gereksinimli birey sayısı 10,447 ve özel sektörde çalışan birey sayısı 101,212 şeklinde, kamuda memur olarak istihdam edilen gereksinimli birey sayısı 53 bin olarak tespit edilmiştir (DPB 2018). Bunun 40 bin kadarı \%40-60 düzeyinde, 5 bini ise \%80-100 düzeyinde gereksinimliliğe sahiptir. Kamuda istihdam edilen lisans diplomalı özel gereksinimli öğretmen sayısı yaklaşık 4 bini bulmaktadır (DPB 2018). Yasaya göre \%3 engelli memur istihdam yükümlülüğü bulunan kamu kurumlarında yaklaşık 9 bin gereksinimli memur istihdam açığı mevcuttur. Diğer yandan bakıma muhtaç (\%70 ve üzeri oranında engellilik) olarak tanımlanan 284,625 kişi, özel gereksinimli birey olarak (\%40-69 engeli) tanımlanan 335,769 kişi sosyal yardım almaktadır (Aile ve Sosyal Politikalar Bakanlığı 2018). Bu istatistikler de ülkemizde gereksinimli bireylere yönelik geleneksel yaklaşımın yani meslek sağlamak yerine hala yardım etme davranışı benimsendiğini göstermektedir (Çaha 2016; Babaoğlu 2018).

\subsection{Dünya'da ve Türkiye'de Mevcut Durum}

Özel gereksinimli bireylere yönelik yapılan çalışmalar tıbbî, hak-temelli ve toplumsal (sosyal) yaklaşımlar şeklinde ele alınmaktadır. Tıbbî yaklaşımda gereksinimlilik durumu bir sağlık problemidir ve çözüme kavuşturulması amaçlanmaktadır. Hak-temelli yaklaşımda, insan hakları ve yurttaşlık eşitliğinin herkese tanınması gerektiği görüşü ile bireylerin yaşadığı sorunların aslında bir insan hakkı ihlâli olduğu vurgulanmaktadır (Okur ve Erdoğan 2010; Özgökçeler ve Alper 2010). Sosyal yaklaşımda ise, bir birey sorun yaşıyor ise sorunun kendisinde değil toplumsal algılardan ve sosyal yaşama katılımda yetersizliklerden kaynaklanmaktadır (Arıkan 2002).

Hak arama mücadeleleri ile başlayan sosyal gelişmeler toplumsal farkındalığı arttırmıştır. Birleşmiş Milletler Özürlü Bireylerin Hakları Beyannamesi ile bireyin saygı görmesi, eğitime ulaşılabilirliği ve meslek edinmesi/istihdamı, aile ve sosyal yaşam kurabilmesi ve hizmete erişilebilirliği haklarının kullanılması ve korunması sağlanmış, ardından 1982 yılında başlatılan Engelliler Için Dünya Eylem Programı ile pek çok ülkede önemli adımlar atılması sağlanmıştır. Bu gelişmeler yaşanırken, ülkemizde de 2005 tarihinde Özürlüler Kanunu yürürlüğe girmiştir. 2011 yılından beri 5378 Sayılı Kanun ile ilgili faaliyetler Aile ve Sosyal Politikalar Bakanlığı'nın Engelli ve Yaşlı Hizmetleri Genel Müdürlüğü tarafından yürütülmektedir. Eşitlik ve toplumsal hayata katılımı sağlayacak sosyal bir modele dayanan Kanun gereksinimli bireylerin toplumla bütünleşmesini amaçlamaktadır. Daha sonra 2015'te Kanunda yapılan değişiklikle bireyin özel bir yaşama düzenine zorlanamayacağı, başkalarından yardım almadan toplum içinde yaşamını bağımsız olarak sürdürmesi ve temel intiyaçlarını karşılaması yer almıştır (5378 Sayılı Kanun). AB'ye uyum sürecinde 2005 yılında yürürlüğe giren Türk Ceza Kanunu'nda nefret ve ayrımcılık ile ilgili maddede engellilik dâhil edilmiş, sosyal dışlanmanın engellenmesine yönelik yeniden düzenlenmiştir. Toplumdaki kırılgan gruplara [engelliler, kadınlar, çocuklar, güçsüzler gibi] karşı farkındalık ve duyarlılığın geliştirilmesi ve yaygınlaştırılmasında, ayrımcılığın ve şiddetin önlenmesi için, Radyo ve Televizyonların Kuruluş ve Yayınları Hakkında Kanun'da bir takım düzenlemelere 
yer verilmiştir (3984 Sayılı Kanun). Devlet Memurluğu Kanunu'nda yapılan değişiklikle engelli memur istihdam yükümlülügü toplam memur kadrolarının \%3'ü olacak şekilde uygulanmaya başlanmıştır (657 Sayılı Kanun). Büyükşehir Belediyesi Kanunu'na ilâve bir madde eklenmesiyle, belediyelerde engellilerle ilgili bilgilendirme, danışmanlık, meslek edinme eğitimleri vermek üzere engelli hizmet birimleri oluşturulmuştur (5216 Sayılı Kanun). Böylece yerel yönetimler bu faaliyetlerini vakıf, dernek ve bunların üst kuruluşlarıyla işbirliği hâlinde sürdürmekte engellilerin, sosyal yaşama katılımında önemli roller üstlenmektedir.

\subsection{Afet Dirençliliği Bakımından Engellilik}

Türkiye'nin de yer aldığı Uluslararası Sendai Afet Risk Azaltma Çerçevesi (2015-2030) kapsamında alınan kararlar, afet yönetimi süreçlerinin her aşamasında öncelikle halkın tüm kesimlerinin katılımının arttırılmasını hedeflemektedir (UNISDR 2015). Uluslararası politika ve uygulamalarına özel gereksinimli bireylerin katılımının sağlanması dâhil edilmiştir. Bu yaklaşımla halkın kırılganlığının azaltılması, hazırlık kapasitesi ve dirençlilik bakımından güçlendirilmesi amaçlanmaktadır (Alexander ve diğ. 2012; Kelman 2018; Arnold ve diğ. 2018; Twigg ve diğ. 2018). Bunun için afet yönetimi evrelerine (zarar azaltma, hazırlık, müdahale ve iyileştirme) yönelik planlama çalışmalarında halkın katılımını sağlamak için yerel organizasyonlarla desteklenecek şekilde düzenlenmesine karar verilmiştir (UNISDR 2017). Buna bağlı olarak, ülkemizde de Afet Acil Durum Başkanlığı (AFAD) Ulusal Deprem Stratejisi ve Eylem Planı (UDSEP 2023) ve Afet Müdahale Planı (TAMP) ile afete dirençlilik bakımından ulusal bir yol haritası hazırlanmıştır.

2016 yılında İstanbul'da gerçekleşen Dünya İnsani Zirvesi, ardından 2017 İstanbul ve 2018 Roma Avrupa Afet Risk Azaltma Forumları gündeminde afetlerin belirli kırılgan grupları orantısız şekilde etkilediği konusu ele alınmıştır. Bu forumlarla temel insan haklarını korunmasına, cinsiyetten bağımsız, insan-odaklı politika ve yaklaşımların uygulanmasına, özel gereksinimli kırılgan gruplar da dahil olmak üzere toplumun tamamının planlama süreçlerine katılımının desteklenmesi kararlaştırılmıştır. Özellikle İstanbul Bildirgesi'nde göçe zorlanan mülteci, yaşlı, engelli ve çocuklar gibi izole grupların da ulusal ve uluslararası afet risk azaltma stratejilerinde ele alınması öncelikli olduğu belirtilmektedir.

Bu bildirgelerin devamında 2018 yılında Dünya Bankası hazırlık kapasitesini geliştirmek amacıyla özel gereksinimliliğe yönelik programların düzenlenmesi ve gereksinimli bireylerin katılımını ve sorumlu olmalarını sağlayan kurumsal bir yapılanma (WB Disability Inclusion and Accountability Framework) oluşturmuştur. İngiltere'de düzenlenen Küresel Engellilik Zirvesi'nde (Global Disability Summit) halka açık tüm kamusal alanların 2020 yılına kadar; halkın kullandığı toplu taşıma veya kentsel ulaşım sistemlerinin özel gereksinimli bireyler başta olmak üzere halkın kullanımına uygun olarak 2025 yılına kadar düzenlenmesi; ayrıca çalışan engelli personel sayısının arttırılması kararı alınmıştır.

Diğer bir gelişme de, Amerikan FEMA kurumu gereksinimli paydaşlarla birlikte afet-öncesi ve sonrası için ulusal ve yerel düzeyde ortaya çıkacak sorunları belirlemiş, ihtiyaçlarına göre alınacak karar, yöntem ve çözümlerin geliştirilmesine yönelik çoklu-gereksinimliliğe duyarlı stratejik bir plan hazırlamış bulunmaktadır (FEMA 2018-2022 Stratejik Planı).

\section{YÖNTEM}

Bu çalışmada, öncelikle yürütülen mevcut afet risk azaltma çalışmalarının özel gereksinimli bireyler bakımından ne düzeyde planlandığı ve yürütüldüğünü belirlemek amaçlanmaktadır. $\mathrm{Bu}$ amaçla nitel araştırma yöntemleri kullanılmış, içerik analizi ve anketleme yapılmıştır. Çalışma kapsamında ilk adımda gereksinimli bireylere yönelik hizmet ve faaliyetler 
açısından, ülkemizin önemli afet mevzuatları arasında yer alan iki ulusal plan UDSEP ve TAMP incelenmiştir (Tablo 1). Ayrıca karşılaştırma yapmak amacıyla Sendai Afet Risk Azaltma Çerçevesi de bu kapsamda değerlendirilmiştir. Uluslararası çerçeve planı anahtar kelimeler olarak engelli, özürlü, kırılgan, incinebilir, hassas, özel gereksinimli, riskli, dezavantajlı grup bakımından incelenmiştir.

Bu değerlendirmelerden elde edilen bulgulara göre afet risk yönetimi bakımından strateji ve eylemler belirlenmiştir. Strateji ve eylemlere yönelik hizmetlerden sorumlular olarak paydaşlar adı altında merkezi yönetim (ve ilgili kuruluşlar), AFAD, yerel yönetim, akademi, özel sektör, uluslararası organizasyonlar Sivil Toplum Kuruluşları (STK), ve halk olmak üzere yedi grup ele alınmıştır.

Çalışmanın ikinci kısmında bilgilendirme ve farkındalık oluşturarak anketleme çalışması ile geri bildirim ile veri toplanmıştır. AFAD tarafından 12-13 Şubat 2019 tarihlerinde düzenlenen Özel Gereksinimli Bireyler İçin Afet Risklerinin Azaltılması Çalıştayı kapsamında "Kırılganlıktan Kapasiteye" başlıklı bildiri ile katılımcılara özel gereksinimli bireylere-duyarlı kapsamlı afet yönetimi anlatılmıştır. Çalışma kapsamında mevzuatların özel gereksinimli bireyler bakımından incelenmesi (Tablo 1'de tartışılan bulgular) ve bu değerlendirmelerden belirlenen stratejik faaliyet önerileri katılımcılara sunulmuştur. Bu bilgilendirmeyi takiben bir anket ile katılımcılardan önerilen bu eylemler ve sorumlulukları değerlendirmeleri istenmiştir. Özel Gereksinimli Bireylere yönelik gerçekleştirilmesi öncelikli çalışmalar olarak eylem faaliyetlerini değerlendirmeleri ve paydaşların sorumluluklarını (5 en yüksek, 1 en düşük değer) olacak şekilde puanlamaları katılımcılardan istenmiştir. Anketi cevaplayan katılımcılardan gelen 68 adet geri bildirim sayısallaştırılarak ilgili görüşlerin yüzde değerleri tablo halinde verilmiştir (Tablo 2). Makalenin 3. Bölümünde bulguların sonuçları ile ilgili değerlendirmelerin detayları verilmektedir.

\section{BULGULAR VE DEĞERLENDİRME}

Çalışma kapsamında incelenen ulusal afet risk yönetimi mevzuatlarının özel gereksinimlilik bakımından ele alınması, stratejik eylemlerin gerçekleştirilmesi ve sorumlu olarak tanımlanan kuruluşlar Tablo 1'de özetlenmektedir. UDSEP depremlerin neden olabilecekleri fiziksel, ekonomik, sosyal, çevresel ve politik zarar ve kayıpları önlemek veya etkilerini azaltmak ve depreme dirençli, güvenli, hazırlıklı ve sürdürülebilir yeni yaşam çevreleri oluşturacak süreçlerin AFAD tarafından koordine edilmesini amaçlamaktadır. Planda özel gereksinimli bireyler riskli, incinebilir gruplar içinde ele alınmaktadır.

UDSEP kapsamında öngörülen strateji depremlerin etkileriyle baş edebilmek üzere riskli gruplara özel düzenleme yapılmasının sağlanacağı şeklindedir. Bu mevzuatta "riskli grup" içinde bulunan alt gruplara yönelik çalışmaların yapılması ve bu stratejilerin afet yönetimi sistemine bütünleştirilmesi gerekliliği vurgulanmaktadır. Özel gereksinimlilik ve kırılganlık durumlarının (sosyal zarargörebilirlikler) afet risklerine maruziyeti arttırmakta olduğu belirtilmektedir (Tablo 1a).

TAMP modüler yapısıyla afet sırasındaki etkin müdahale kapasitesini geliştirmeyi, afet ve acil durum operasyonlarında görev alacak kamu kurumları, özel sektör, sivil toplum kuruluşları ve gerçek kişileri kapsamaktadır. TAMP kapsamında "incinebilir gruplar" adı altında konuya değinilirken özel gereksinimli bireyler ele alınmamaktadır. Bu grupların olay bölgesinde yer alabileceği ve özel güçlendirme çalışmalarının yapılması gerektiği vurgulanmaktadır (Tablo 1b).

Uluslararası Sendai Afet Risk Azaltma Çerçevesi ile ülkelerin tüm politika ve uygulamalarında engellilik perspektifinin dâhil edilmesi, eşitlikçi ve evrensel erişilebilirlik, 
müdahale ve iyileştirme evrelerinde bireylerin ihtiyaçlarına uygun planlama ve evrensel tasarım ilkelerinin dikkate alınmasının gerekliliği ifade edilmektedir (Tablo 1c).

Ulusal UDSEP ve TAMP planlarında yer alan strateji ve eylemler, özel gereksinimli bireylere yönelik hizmetler ile uluslararası plan olan Sendai Afet Risk Azaltma Çerçevesi hak-temelli yaklaşım bakış açısı (Okur ve Erdoğan 2010; Kalyon 2012) ile değerlendirildiğinde:

- Mevzuatlarda da belirtildiği gibi hakkaniyete uygun eşit koşullarda yaşamak tüm bireylerin hakkıdır,

- Tüm bireyler gibi özel gereksinimli bireylerin de doğuştan herkesle eşit haklara sahip olması gerekmektedir,

· Özel gereksinimli bireylerin sosyal yaşama aktif katılımı desteklenmeli, göz ardı edilmemelidir,

- Özel gereksinimli kimliğinin bir hak-problemi olduğunun kavranması ve çözüme kavuşturulması gerekliliği görülmektedir,

- Gereksinimli bireylere yönelik afet farkındalık ve hazırlık eğitimleri adı altında tek-yönlü bilgi verilmesi yeterli değildir,

- Katılımcı afet risk yönetiminde paydaş olarak yer alması ve uygulamada işlerlik kazandırılması bakımından önem arz etmektedir.

UDSEP kapsamında belirtilen eylemler farklı özellikteki bireyleri hassas gruplar adı altında bir arada ele almaktadır. Ancak her bir grubun ayrı ayrı dikkate alınması gerekliliğini de vurgulamaktadır. Bu grupların kırılgan durumlarından ötürü risklere açık daha fazla zarar gördükleri ifade edilmektedir. Sosyal bağların, güç ilişkilerinin, bilgi ve yeteneklerinin ve kapasite düzeyleri ile yerleşimlerin zarargörebilirliği etkilediği belirtilmektedir. Bu bakış açısı bakımından planın "toplumsal yaklaşımı" barındırdığı söylenebilir.

Özel gereksinimli bireylere yönelik ayrımcılığın önlenmesi talepleri zamanla engellilerin hak mücadelesine dönüşmüştür. "Avrupa Birliği Temel Haklar Şartı" ve "Özürlüler İçin Engelsiz Avrupa Tebliği” birey özelinde ayrımcılıkları reddetmiş ve bireylerin haklarının eşit vatandaşlık teminatı altında savunulması gereğini ortaya koymuştur (BM 2008). Bu bağlamda, gereksinimli bireylere yönelik politikaların eşit yurttaşlık temelinde geliştirilmesine intiyaç vardır.

TAMP gibi önemli bir ulusal müdahale planında incinebilir gruplar başlığı bütünüyle ele alınmıştır; bu gruplara yönelik özel durumlar veya bir bakış açısı sunulmamıştır. Örneğin, kurtarma ekipleri uygulamada genel insani intiyaçları göz önüne alacak şekilde müdahale hazırlığı yapmaktadır. Bu durum, afetlerde özel gereksinimli bireylere yetersiz (veya uygun olmayan) hizmetin sunulmasını sağlamaktadır. Otistik birey tanımadığı ortam ve kişilerle daha zor iletişim kurar, bunun için afette engelliye yardım etmek onun intiyaçlarına uygun özel yöntem ve hazırlık gerektirir. Arama kurtarma ekiplerinin bu gruplarla iletişim düzeylerini geliştirmek üzere ancak özel gereksinimli bireylerle birlikte tatbikat yaparlarsa afet hazırlık kapasitesini geliştirebilir. Gereksinimli bireylerin kendilerini afet esnasında daha iyi korumasının ve ihtiyaçlarının karşılanmasının yansıra kapasitelerinin afet öncesinde değerlendirilmesi sayesinde de afet sonrasında ekiplerin daha etkin çalışmaları sağlanabilir.

Özel gereksinimli bireyin kapasitesini dikkate alan politikalar bu sosyal değişimi geliştirme ve sürdürmede temel araç olarak kullanılabilir. Kuşkusuz gereksinimli bireylerin sorunlarını, intiyaçlarını ve beklentilerini görmezden gelmek ya da önemsememek de ayırımcılık olmakta ve durumları acınılacak, incinebilir, kırılgan gruplar olarak değerlendirilmesini sağlamaktadır. Politika belirlenirken bu ayırımcılıkların aşılmasına yönelik faaliyetlere önem verilmelidir. 
Tablo 1. İlgili mevzuatların çalışma kapsamında değerlendirilmesi

\begin{tabular}{|c|c|c|c|c|c|}
\hline \multirow{2}{*}{ Mevzuat } & \multirow{2}{*}{\begin{tabular}{|l} 
Yayın \\
Tarihi
\end{tabular}} & \multirow{2}{*}{ İlgili Hedef, Strateji, Eylem } & \multirow{2}{*}{ Planlanması hedeflenen } & \multicolumn{2}{|c|}{ Sorumlu Kuruluşlar } \\
\hline & & & & Koordinatör & Illgili \\
\hline \multicolumn{6}{|l|}{$1 \mathrm{a}$} \\
\hline $\begin{array}{l}\text { UDSEP } \\
2023\end{array}$ & 2011 & $\begin{array}{l}\text { Eksen C: Depremlerin } \\
\text { etkileriyle baş edebilmek } \\
\text { Hedef C.2: Deprem stratejisinin } \\
\text { bütüncül ve etkin bir hale } \\
\text { getirilmesi için mevzuat } \\
\text { düzenlemelerinin } \\
\text { gerçekleştirilmesi } \\
\text { Strateji C.2.3: Riskli birey } \\
\text { grupları için özel düzenleme } \\
\text { yapılması sağlanacaktır. } \\
\text { Eylem 2.3.1: Riskli birey } \\
\text { grupları ile afet riski belirleme } \\
\text { çabalarını birleştirecek ulusal } \\
\text { düzeyde bir toplantı yapılarak } \\
\text { gerekli düzenlemeler } \\
\text { gerçekleştirilecektir. }\end{array}$ & $\begin{array}{l}\text { - Toplumun önemli çoğunluğunu oluşturan kadınlar, } \\
\text { çocuklar, yaşlılar ve engelliler özelinde } \\
\text { çalışmaların yapılması } \\
\text { - Bu çalısmaların sonuçlarının da afet yönetimi } \\
\text { sisteminin içine dâhil edilmesi gerekmekte } \\
\text { - Afetlerle baş edebilme kapasitesinin arttııııması ve } \\
\text { zarargörebilirliğin azaltılıası planlanması } \\
\text { hedeflenmektedir. } \\
\text { Değerlendirme: } \\
\text { kişilerin ve sosyal grupların sosyal bağları, güç } \\
\text { iliş̧ileri, bilgi ve yetenekleri, toplumsal cinsiyet rolleri, } \\
\text { sağlık ve ekonomik gelişmişlik düzeyleri ve } \\
\text { yerleşimlerinin birer fonksiyonudur. Bu süreçlerde } \\
\text { kadınların, çocukların, yaşlıların ve engellilerin zayıf } \\
\text { konumları da zarargörebilirliklerini arttırıcı birer etken } \\
\text { olarak yer almaktadır. }\end{array}$ & AFAD & \begin{tabular}{|l} 
\\
\\
Aile ve Sosyal \\
Politikalar \\
Bakanlığı, \\
il Özel İdareleri, \\
Sivil Toplum \\
Kuruluşları (STK)
\end{tabular} \\
\hline \multicolumn{6}{|l|}{$1 b$} \\
\hline TAMP & 2013 & & $\begin{array}{l}\text { - Olay bölgesinde incinebilir gruplar ve yabancı } \\
\text { uyruklu kişilerin olabileceği, } \\
\text { - Incinebilir grupların intiyaçlarına özel güçlendirme } \\
\text { çalışmalarının yapılması }\end{array}$ & AFAD & \begin{tabular}{|l} 
Aile ve Sosyal \\
Politikalar \\
Bakanlığı, \\
Diyanet Işleri \\
Bakanlığı, \\
Gençlik ve Spor \\
Bakanlığı, \\
Içişleri Bakanlığı, \\
Kültür ve Turizm \\
Bakanlığı, \\
Milli Eğitim \\
Bakanlığı, \\
Sağlık Bakanlığı, \\
Kızılay, \\
Yerel Yönetimler, \\
Universiteler, \\
STK, \\
Özel Sektör
\end{tabular} \\
\hline \multicolumn{6}{|l|}{ 1c } \\
\hline $\begin{array}{l}\text { Sendai Afet } \\
\text { Risk } \\
\text { Azaltma } \\
\text { Çerçevesi }\end{array}$ & 2015 & $\begin{array}{l}\text { Öncelik 4: } \\
\text { Etkili müdahale için afete } \\
\text { hazırlık (çalışmalarını } \\
\text { gelişstirmek), } \\
\text { lyileştirme ve "Öncekinden } \\
\text { Daha Iyisini İş̧a Etmek", } \\
\text { Paydaşların rolünü arttırmak, }\end{array}$ & \begin{tabular}{|l} 
- On yıllık zaman diliminde afetler nedeniyle ülkelerin \\
refahı ve güvenliği etkilenmiş, yedi yüz binden \\
fazla insan hayatını kaybetmiş, 1.4 milyondan \\
fazlası yaralanmış, yaklaşık 23 milyon insan \\
evsiz kalmıs ve 1.5 milyar insan çeşitli şekillerde \\
etkilenmiştir: özellikle incinebilir bireyler, \\
kadılılar, çocuklar fazlasılyla zarar görmüştür \\
- Afet risklerinin azaltılıası, toplumun tüm kesimlerinin \\
sorumluluğu, paylaşımını veya ortaklığııı \\
- Özellikle de afetlerden orantısız etkilenen toplumun \\
kesimlerinin güçlendirilmesi, hizmetlere erişimi \\
ve \\
- Tüm politika ve uygulamalarda cinsiyet, yaş, \\
engellilik ve kültürel perspektifin dâhil edilmesi \\
ve katılımının sağlanmasını, \\
(Engelli bireyler ve ilgili kuruluşlar; afet risklerinin \\
değerlendirilmesinde ve söz konusu bireylerin \\
intiyaçlarına dikkate alarak planların, \\
oluşturulmasında ve uygulanmasında kritik \\
öneme sahiptir) \\
- Halkın gönüllü organize olmasının desteklenmesini \\
gerektirmektedir. \\
(Kadınları ve engellileri, cinsiyet eşitlikçi ve evrensel \\
olarak erişilebilir müdahale, iyilesstirme ve yeniden inşa \\
yaklaşımlarının açıkça yönlendirilmesi ve \\
desteklenmesi için yetkilendirmek esastır)
\end{tabular} & & \begin{tabular}{|l} 
\\
\\
\\
STK \\
(Yerel, Ulusal, \\
Uluslararası \\
Organize \\
Resmi/Yarı- \\
Resmi Kuruluşlar)
\end{tabular} \\
\hline
\end{tabular}




\subsection{Eylem Önerileri}

Araştırmacılar tarafından yapılan değerlendirmelere göre kapsamlı afet risk yönetimi için 6 adet eylem önerilmektedir: çoklu-veri toplanması (1) ve araştırmaların desteklenmesi (2), fiziksel engellerin azaltılmasına yönelik mimari erişimin sağlanması (3), sosyal engelliliğin azaltııması için farkındalık çalışmaları (4), dirençliliğe yönelik kapasitenin arttırılması (5), katıımcı planlama (6). Bu değerlendirmeler sonucunda

\section{UDSEP için:}

- Toplumun önemli çoğunluğunu oluşturan kadınlar, çocuklar, yaşlılar ve engelliler özelinde çalışmaların yapılması için $(1,3,4,6)$ nolu eylemler,

- Çalışmaların sonuçlarının da afet yönetimi sisteminin içine dâhil edilmesi için (5) nolu eylem - Afetlerle baş edebilme kapasitesinin arttırılması ve zarar görebilirliğin azaltılması (3 ve 4) nolu eylemler önerilebilir.

TAMP için

- Olay bölgesinde incinebilir gruplar ve yabancı uyruklu kişilerin olabileceği (1 ve 2) nolu eylemler,

- İncinebilir grupların intiyaçlarına özel güçlendirme çalışmalarının yapılması (5) nolu eylem uygulamada yardımcı olması düşünülen faaliyetlerdir.

Sendai Risk Azaltma Çerçevesi kapsamında

- Özellikle gereksinimli bireyler, kadınlar, çocuklar fazlasıyla zarar gördüğüne dikkat çekilmektedir, bunun için (1 ve 6 ) nolu eylemler

- Afet risklerinin azaltılması, toplumun tüm kesimlerinin sorumluluğu, paylaşımını veya ortaklığı için (5),

- Tüm politika ve uygulamalarda cinsiyet, yaş, engellilik ve kültürel perspektifin dâhil edilmesi ve katılımının sağlanması için (2) nolu eylemlerin hayata geçirilmesi önerilebilir.

\subsection{Katılımcı Değerlendirme ve Sorumlulukların Tartışılması}

Önerilen bu eylemlerle ilgili sorumluların ilişkilendirilmesi katılımcı planlamada önemli yer tutmaktadır. Çalışmanın ikinci bölümünde Özel Gereksinimli Bireyler İçin Afet Risk Azaltma Çalıştayı'na katılan katılımcıların geri bildirimleri değerlendirilmektedir. Özel gereksinimli bireylere duyarlı afet yönetimi modeli kapsamında geliştirilen eylem önerileri katılımcılara sorulduktan sonra elde edilen geri bildirimler aşağıda özetlenmektedir. Katılımcıların belirttiği sorumlulukların dağılımı ile ilgili görüşler değerlendirilerek yüzde değer olarak Tablo 2'de sunulmaktadır. 
Tablo 2. Özel gereksinimli bireylere-duyarlı afet risk yönetimine yönelik stratejik eylem faaliyetleri ve paydaşların sorumluluklarının değerlendirilmesi kapsamında verilen anket formları ve katıımcı görüşleri yüzde dağılımı

\begin{tabular}{|c|c|c|c|c|c|c|c|c|}
\hline \multirow{2}{*}{$\begin{array}{l}\text { Öncelikli } \\
\text { Stratejiler }\end{array}$} & \multirow[b]{2}{*}{ Eylemler } & \multicolumn{7}{|c|}{ Paydaşlar/Sorumlulukları (\%) } \\
\hline & & $\begin{array}{c}\text { Merkez } \\
\text { i } \\
\text { Yöneti } \\
\text { m }\end{array}$ & $\begin{array}{c}\text { AFA } \\
\text { D }\end{array}$ & $\begin{array}{c}\text { Yerel } \\
\text { Yöneti } \\
\text { m }\end{array}$ & $\begin{array}{c}\text { Akade } \\
\text { mi }\end{array}$ & $\begin{array}{c}\text { Özel } \\
\text { Sektö } \\
r\end{array}$ & $\begin{array}{l}\text { ST } \\
\text { K }\end{array}$ & $\begin{array}{c}\mathrm{Hal} \\
\mathrm{k}\end{array}$ \\
\hline \multirow{2}{*}{$\begin{array}{l}\text { Gereksinimliliği } \\
\text { n tanımı: } \\
\text { karmaşıkı̆̆ı, } \\
\text { dağılııı }\end{array}$} & $\begin{array}{l}\text { (1) Çoklu- } \\
\text { Veri toplama }\end{array}$ & 32 & 11 & 22 & 18 & 5 & 10 & 3 \\
\hline & $\begin{array}{l}\text { (2) } \\
\text { Araştırmaları } \\
\mathrm{n} \\
\text { desteklenme } \\
\text { si }\end{array}$ & 24 & 14 & 14 & 17 & 12 & 11 & 8 \\
\hline $\begin{array}{l}\text { Engellerin } \\
\text { azaltılması: } \\
\text { >Sosyal hayata } \\
\text { katılım } \\
\text { >Fiziksel } \\
\text { erişilebilirlik }\end{array}$ & $\begin{array}{l}\text { (3) Fiziksel } \\
\text { erişimin } \\
\text { sağlanması }\end{array}$ & 29 & 9 & 29 & 9 & 11 & 7 & 6 \\
\hline >Sosyal engeller & $\begin{array}{l}\text { (4) Sosyal } \\
\text { engellerin } \\
\text { azaltılması, } \\
\text { farkındalık }\end{array}$ & 19 & 13 & 17 & 13 & 12 & 12 & 14 \\
\hline $\begin{array}{l}\text { Kapasite } \\
\text { geliştirme: } \\
\text { >İstihdamın } \\
\text { arttıııması }\end{array}$ & $\begin{array}{l}(5) \\
\text { Kapasiteye } \\
\text { yönelik } \\
\text { programların } \\
\text { geliştirilmesi }\end{array}$ & 23 & 14 & 16 & 17 & 10 & 13 & 7 \\
\hline $\begin{array}{l}\text { >Gönüllülük } \\
\text { Risk Yönetimi } \\
\text { Dirençliliğin } \\
\text { geliştirilmesi }\end{array}$ & $\begin{array}{l}\text { (6) Katılımcı } \\
\text { planlama }\end{array}$ & 16 & 16 & 18 & 12 & 11 & 14 & 13 \\
\hline
\end{tabular}


(1) Her ne kadar birçok ülke engelli insanların yaşam koşullarını geliştirmek için çeşitli çalışmalar yürütülmekteyse de yapılması gereken henüz çok şey vardır. Bunların başında çoklu-gereksinimlilik ile ilgili veri toplama sistemi geliştirilmesi gereklidir. Yerel veri yeterli olmadığı için planlama yaklaşımlarında, ya hiçbir şey yapmamak, ya da merkezi bir planlama anlayışı tercih edilmektedir. Bu çalışmada yapılan anket değerlendirmesinden çoklu-veri toplanmasına yönelik çalışmalardan sorumlu olarak \%32 ile merkezi yönetim, \%11 ile AFAD, \%22 ile yerel yönetim sorumlu görülürken \%18 ile akademi ve \%10 ile STK sorumlu olması görüşü bildirilmektedir. Veri erişiminin sağlanmasına yönelik hizmet merkezi yönetim ve yerel yönetimle ilişkilendirilmektedir (Tablo 2). Bu sonuçlara göre tüm paydaşların bir araya gelip afetlerdeki zararları ve yaşam riskini en aza indirmek için karşılıklı bilgi alışverişinde bulunmaları ve bunun için veri toplamaları afete hazırlık programlarının katılımcı bir şekilde geliştirilmesi açısından önemlidir.

(2) Özel gereksinimlilik ile ilgili konularda toplumun anlayışının geliştirilmesi, kapsayıcı politika/ programların yönlendirilmesi ve kaynakların etkin bir şekilde dağıtılması için araştırmaların yapılması desteklenmelidir. Bunun için ankete katılan katılımcılar merkezi (\%24) ve yerel yönetim (\%14) ve AFAD (\%24) tarafından projeleri desteklemesi gerektiği şeklinde görüş bildirirken akademi, özel sektör ve halkın da projelerin içinde yer alması gerektiğini belirtmişlerdir (Tablo 2).

(3) Gereksinimli bireylerin sağlık ve refah, ekonomik ve sosyal güvence, kendilerini yetiştirmek ve becerilerini geliştirmek gibi sıradan ihtiyaçları vardır. Bu ihtiyaçlar halkın tüm kesimleri için ayrıştııılmadan karşılanmalıdır. Bütün kamusal sistem ve hizmetlere erişimin sağlanması dirençliliğe yönelik yeniden yapılanmada en önemli stratejik adım olmalıdır. Her insanın kentsel yaşama katılabilmesi için yapılaşmış çevrenin onu engellememesi sağlanmalıdır. Bunun için mimari erişilebilirliğin sağlanması ve erişilebilirlik standartlarına uygun olarak yapılması, toplu taşıma araçlarının düzenlenmesi öncelikli konudur. Katılımcılar hem merkezi hem de yerel yönetimin (\%29) ayrıca özel sektörün (\%11) de her türlü fiziksel erişilebilirliği sağlamakla sorumlu olduğu görüşünü bildirmişlerdir (Tablo 2).

(4) Gereksinimli bireylere yönelik yerleşmiş olumsuz kültür, toplumsal kırılganlığı daha da arttırmaktadır. Çevresel koşulların yansıra toplumsal tutumlar nedeniyle de bireyler sorun yaşayabilmektedirler. Bu olumsuz algılara karşı farkındalık ve anlayışın geliştirilmesi, dirençlilik bakımından ele alınması gereken önemli bir konudur. Gereksinimli bireylere yönelik tutum ve davranışların değişmesi için, engellilerin hayatın her aşamasında engelli olmayan kişiler ile birlikte olmalarını sağlayacak düzenlemelerin yapılması gereklidir. Bu toplumsal dışlanmanın engellenmesi için gereksinimli bireylerin toplumda daha görünür hâle gelmesi gereklidir. Bu sürecin her aşamasında ihtiyaç ve tercihlerinin dikkate alınması, merhamet gösterip yardım etmek yerine, onların da haklarının olduğu bilincine varmak bu yönde atılacak adımların başlangıcını oluşturacaktır.

Yerel yönetimler, gönüllü kuruluşlar ve medyanın duyarlılık ve bilinç düzeyinin yükseltilmesine yönelik eğitim ve bilgilendirmenin yapılması ve başarı hikâyelerinin kamu spotları ile anlatıması önem taşımaktadır. Bu bağlamda, toplumsal önyargıların azaltılmasına yönelik eğitim programlarının oluşturulmasında önemli roller üstlenebilirler. Bu çalışmalar özel gereksinimli bireyleri anlamak ve onlarla iletişim kurmak için sahadaki uzmanların eğitimlerini de içermelidir. Örneğin, AFAD uzmanlarının gereksinimli bireyleri anlaması, sahada birlikte çalışması konusunda eğitim almaları sağlanmalıdır. Bu yaklaşım sosyal engellerin azaltılması ve bireylerin bağımsız sosyal yaşama katılımı için öncelikle ele alınması müdahale ve geçici barınma evrelerinin başarısını sağlayacaktır. Bu çalışmada yapılan anket sonuçlarından katılımcıların sosyal engellerin azaltılmasında genel olarak herkesin sorumlu olduğu şeklinde görüş bildirdiği görülmektedir (Tablo 2). 
(5) Özel gereksinimli bireyleri kırılgan bireyler yerine insan kaynağı olarak kabul eden yaklaşım ile kapasite geliştirme hedeflenmelidir. Gereksinimli bireyler her alanda başarılı olabildiği gibi afet risk azaltma çalışmalarında da başarı örnekleri artırılmalıdır. Özel gereksinimli bireylerin kapasiteleri değerlendirilip çaresiz, savunmasız, kurban olarak değil, becerileri ve hatta güçlü yönleriyle planlama ve uygulamada eyleme geçirilmeleri sağlanmalıdır. Bu bireylerin afet öncesinde hazırlık faaliyetlerinde, afet sırasında kurtarma operasyonları da dâhil olmak üzere, mahalle çalışmalarında destekleyici rollerinden yararlanılabilir. Özel gereksinimli bireylerle yaşlıların da kapasitelerini ortaya koymak ve değerlendirmek üzere geliştirilecek programlarla bütünleştirilmesi insan kaynağı kapasitesini arttırmak bakımından atılacak stratejik adımlardan olmalıdır.

Toplumun değişen sosyal özellikleri, halkın hazırlık ve müdahale kapasitelerini etkilemektedir. Buna göre, bir afet durumunda bireylerin verdiği tepki ve afetle başa çıkma kapasitesi farklıık gösterecektir. Bu yüzden her bireyin sahip olduğu kapasitenin geliştirilip yerel afet yönetimi süreçlerine katılmaları, afete hazırlık için büyük önem kazanmaktadır. Bu bakımdan insan hakları ilkeleri, engellilik ile ilgili mevcut müfredat ve akreditasyon programlarına dâhil edilmeli, yerelde de (İl Engelli Müdürlüğü, İlçe Engelli Koordinasyon Merkezleri) mesleki iyileştirme ve eğitim ile işgücü piyasası fırsatlarının (daha fazla istihdam) önü açılmalıdır. Örneğin gelişen teknolojiyle bilişim sektöründe özel gereksinimli bireylere yönelik yapılacak çok iş olanağı açılmıştır. Toplumun bu kesiminin daha fazla istihdam edilmesi sosyo-ekonomik gelişimi hızlandıracaktır. Bu çalışma kapsamında ankete katılan katılımcılar özel programlar ve hizmetler geliştirilmesinden merkezi yönetim (\%23) ve AFAD (\%14) üniversiteler (\%17) başta olmak üzere yerel yönetimin (\%16) sorumlu olduğunu belirtmektedir (Tablo 2).

(6) En gelişmiş yaklaşım; ulusal veya yerel bir stratejinin geliştirilmesi, uygulanması ve izlenmesi ilgili tüm sektörleri (paydaşları) bir araya getiren katılımcı planlamadır. $\mathrm{Bu}$ yaklaşım, eylem planı, kısa ve orta vadede gerçekleştirilecek strateji, politika ve uygulamalar düzenlenirken özel gereksinimli bireylere danışılması ve engellilerin bu sürece aktif olarak dâhil edilmesini sağlayacaktır. Gereksinimli bireyler kendi durumları hakkında daha farklı ya da daha duyarlı düşünmektedir. Yerel yönetim araçlarından kent konseylerinde gereksinimli bireylerin yer alması potansiyel sorun ve çözümlerin belirlenmesinde duyarlı afet risk yönetimini geliştirecektir. Ayrıca mahalle hazırlık sisteminin geliştirilmesi, gereksinimli bireylerin de bu organizasyonlara dâhil edilmesi hazırlık ve müdahale kapasitesini, dolayısıyla dirençliliği arttıracaktır. Bu çalışmada anket sonuçlarından dirençlilik bakımından katılımcı planlamanın geliştirilmesi ve uygulanmasında herkesin sorumlu olduğu şeklinde görüş bildirildiği görülmektedir (Tablo 2).

\section{SONUÇLAR}

Özel gereksinimli bireyler dünyanın her yerinde istihdam koşullarının yetersizliği, işsizlik, yoksulluk ve düşük gelir, yetersiz kentleşmenin getirdiği mimari erişilebilirliğin sağlanamaması, ayrışmış eğitim sistemi gibi çok çeşitli ve çok boyutlu sorunlarla karşı karşıyadırlar. Özel gereksinimli bireylere duyarlıık, genellikle görme ve işitme veya tekerlekli sandalye kullanıcılarının sağlık intiyaçlarına yönelik cihaz sağlamaya yönelik bir yaklaşım şeklindedir. Gereksinimli bireylere karşı olumsuz toplumsal algının getirdiği fiziksel, duygusal ve cinsel şiddet gündelik yaşamı çok ciddi şekilde etkilemektedir.

Yapılan araştırmalar gereksinimli bireyin kendisine ait engelliliğin değil toplumdaki sosyal engellerin sorun oluşturduğunu göstermektedir. Gereksinimlilik genel olarak bir sağlık sorunu olarak ele alınmış, eğitim, istihdam ve hizmetlere erişebilirlik gibi temel düzenlemelerle ilgili sosyal politikalar gecikmiştir. Tıbbî yaklaşımın hâkim olduğu görülürken, normal insanlara göre düzenlenmiş olan sosyal yaşamda gereksinimli bireylere yönelik hak- 
temelli sosyal bütüncül uygulamalar bu bireyler için söz konusu olamamıştır. Bu durum hem özel gereksinimli bireylerin sorunlarının göz ardı edilmesine, hem de sosyal yaşamdan dışlanmasına, ayrımcı tutumlara maruz kalmalarına neden olmaktadır. $\mathrm{Bu}$ anlamda engellileri yetkilendirme ve sosyal hayata dâhil olabilme uygulamada sorunludur. Bakım ve takip programlarının güçlendirimesi, önleme programlarının dikkatle hazırlanması gibi tıbbî yaklaşımı betimleyen çalışmaların yansıra sosyal yaklaşımın (benimsenmesi gereksinimli bireyler için son derece büyük önem taşımaktadır. Çeşitli araştırmacıların da belirttiği gibi gereksinimli bireylere özel hizmetler ve intiyaç duyduğu tıbbî süreçlerin "sosyalleştirilmesi" gerektiğini burada vurgulamakta yarar vardır.

Türkiye'de AFAD Afet Risk Azaltma çalışmaları ile önemli ilerlemeler kaydedilirken geliştirilen yol haritasında, uygulamada tüm kesimlerin katılımı yetersizdir. UDAP kapsamında yürütülen projeler de özel gereksinimliliğe yönelik çalışma yer almamaktadır. Birleşmiş Milletler tarafından geliştirilen Küresel Sürdürülebilir Kalkınma Hedefler (SKH) kapsamında ortaya çıkan sosyal yaklaşım kampanyaları ("\#Kimseyi Geride Bırakma"-"\#Engelliler olmadan asla"- \#Leave no one behind) ise dünya genelinde olduğu gibi ülkemizde de giderek kabul görmekte ve yaygınlaşma çabaları sürmektedir.

$\mathrm{Bu}$ çalışmada sunulan anket sonuçlarından da görüldüğü gibi toplumun tüm kesimlerinin paydaş olarak sorumlu olduğu tüm süreçlerine katıldığı kapsamlı afet risk yönetimi anlayışının uygulamada atılacak adımların başında gelecektir. Afete dirençlilik bakımından başta yerel yönetimler olmak üzere birlikte düşünebilme ve davranabilmeli, katılımcı yaklaşımını benimsemelidirler. Özel gereksinimli bireylere hizmet veren kurum ve gönüllü tüm kuruluş yetkililerinin ortaklaşa çalışmaları, merkezi ve yerel politika hazırlama süreçlerine katılmaları yaşamsaldır. Sorunlarının ve bunlara yönelik çözüm yollarının saptanması ve karar aşamasında özel gereksinimli bireylerin katılımı, bireylerin görünür hale gelmesini sağlamak, toplumun bir kesiminin yokmuş gibi görülmesi veya engellemesinin azaltılması, kapasitelerinin geliştirilmesinde etkili olacaktır. Bu yaklaşımla gereksinimliliklere-duyarlı kapsamlı (kapsayıcı) afet yönetimi ile toplumsal dirençlilik sağlanmış olacaktır.

\section{Teşekkür}

12-13 Şubat 2019 tarihlerinde Özel Gereksinimli Bireyler İçin Afet Risklerinin Azaltılması Çalıştayının düzenlenmesinde AFAD başta olmak üzere, Anadolu Üniversitesi ve Eskişehir Teknik Üniversitesi ve düzenleme komisyonuna, anket sırasında yardımları için Eskişehir AFAD ve Karamanoğlu Mehmetbey Üniversitesi öğretim elemanı Fırat Aslangiri, değerli görüşleri için Kocaeli Üniversitesi öğretim üyesi Prof. Dr. Gönül Balkır’a teşekkür ederiz. 


\section{KAYNAKLAR}

AFAD (2012). Stratejik Plan. https://www.afad.gov.tr/tr/2402/AFAD-Baskanligi-Stratejik-Plani

AFAD (2012). Ulusal Deprem Strateji Planı (UDSEP). https://www.afad.gov.tr/tr/2414/UDSEP-2023

AFAP (2015). Türkiye Afet Müdahale Planı (TAMP). https://www.afad.gov.tr/tr/2419/Turkiye-AfetMudahale-Plani

AFAD Ulusal Deprem Araştırma Programı (UDAP). https://www.afad.gov.tr/tr/24213/Ulusal-DepremArastirma-Programi-UDAP; https://deprem.afad.gov.tr/icerik?id=10\&menuld=100

AFAD Paydaşlar Listesi. https://www.afad.gov.tr/tr/2407/Paydaslar

Aile ve Sosyal Politikalar Bakanlığı (2017). Erişilebilirlik: İzleme ve Denetleme, Engelli ve Yaşlı Hizmetleri Genel Müdürlüğü, Ankara.

Aile ve Sosyal Politikalar Bakanlığı (2018). Engelli ve Yaşlı Bireylere Yönelik İstatistikler. Engelli ve Yaşıı Hizmetleri Genel Müdürlüğü, Ankara.

Alexander D., Gaillard J.C., Wisner B. (2012). Disability and Disaster. In: B. Wisner, JC Gaillard, I. Kelman (eds), Handbook of Hazards and Disaster Risk Reduction. Routledge, New York, pp 413-423.

Arıkan Ç. (2002). Sosyal Model Çerçevesinde Özürlülüğe Yaklaşım. Ufkun Ötesi Bilim Dergisi, 2 (1):11-25.

Arnold M., McClain-Nhlapo C., Raja S.D., Piccio L. (2018). Five actions for disability-inclusive disaster risk management. https://blogs.worldbank.org/sustainablecities/leaving-no-one-behinddevelopment-roadmap-disability-inclusion

Aslan M., Şeker S. (2011). Engellilere yönelik toplumsal algı ve dışlanmışlık. Sosyal Haklar Uluslararası Sempozyumu Bildiri Kitapçığı, 449-463.

Babaoğlu C. (2018). Türkiye'de Anakentlerde Engellililere Yönelik Hizmetler ve Sorun Alanları, TESAM Akademi Dergisi, 79-110.

Birleşmiş Milletler (2008). Birleşmiş Milletler Engelli Hakları Sözleşmesi, www.un.org/disabilities/documents/natl/turkey.doc.

Çaha H. (2016). Engellilerin Toplumsal Hayata Katılmasına Yönelik Politikalar: Türkiye, ABD ve Japonya Örnekleri. Insan ve Toplum, 5 (10): 123-150.

DBP (2018). http://www.dpb.gov.tr/tr-tr/istatistikler/engelli-personel-ve-omss-istatistikleri

Engelsiz Erişim. https://www.engelsizerisim.com/detay/turkiyedeki-korler-okullari/

FEMA 2018-2022 Strategic Plan. http://www.fema.gov/strategic-plan

Hürriyet (2012). Engelli Komşu İstenmiyor. http://www.hurriyet.com.tr/engelli-komsu-istenmiyor20906837.

Kalyon H. (2012). Bülent Ecevit Üniversitesi'nde Engelli Öğrenci Biriminin Yeniden Yapılandırılması. Yükseköğretim ve Bilim Dergisi, 2 (1): 63-68.

Kelman I. (2018). People with Disabilities and Disasters. In: H. Rodríguez, W. Donner, J. Trainor (eds) Handbook of Disaster Research. Sociology and Social Research. Springer, Cham.

Kırıkkaya B. E., Gerdan S. (2018). Engelli ve Engelli Adayı Bireylerin Bir Afet Anında Nasıl Davranacaklarına İlişkin Görüşleri. Resilience, 2(2): 123-129.

Kumtepe H. (2002). Ankara İlinde Yaşayanların Engellilere Yönelik Tutumları (Yayınlanmamış Yüksek Lisans Tezi) Ankara: Hacettepe Üniversitesi Sosyal Bilimler Enstitüsü. 24.

Murat S. (2009). Genel Olarak Özürlülere Yönelik Çalışmalar ve ISMEK Örneği, Sosyal Siyaset Konferansları Dergisi, Sayı: 56, 21-89.

Okay N., Ilkkaracan İ. (2018). Toplumsal Cinsiyete Duyarlı Afet Risk Yönetimi / Resilience 2 (1): 1-12.

Okur N., Erbil-Erdogan F. (2010). Sosyal Haklar ve Özürlüler: Özürlülük Modelleri Bağlamında Tarihsel Bir Değerlendirme. II. Sosyal Haklar Ulusal Sempozyumu Bildiri Kitabı, Denizli Pamukkale Üniversitesi Yayınları, 245-263.

Otsimo (2018). https://otsimo.com/tr/turkiyede-otizmli-cocuk-sayisi/

Özgökçeler S., Alper Y. (2010). Özürlüler Kanunu'nun Sosyal Model Açısından Değerlendirilmesi. İşletme ve Ekonomi Araştırmaları Dergisi, 1(1): 33-54.

Özida projesi (2010). https://ailevecalisma.gov.tr/eyhgm/sayfalar/istatistikler/

TC Cumhurbaşkanlığı Strateji ve Bütçe Başkanlığı. http://www.surdurulebilirkalkinma.gov.tr/amaclari/

TBMM (2008). Birleşmiş Milletler Engelli Hakları Sözleşmesi.

http://www.ozida.gov.tr/ulasilabilirlik/Belgeler/2 mevzuatstandart/uluslararasi sozlesme/bm e ngellihaklarisozlesmesi.pdf

TÜIK (2011). Özürlülerin Sorun ve Beklentileri Araştırması, Türkiye İstatistik Kurumu. http://www.tuik.gov.tr/prehaberbultenleri. do?id=6370. 
TÜIK (2015 ve 2017). Türkiye Demografik İstatistikler, Türkiye İstatistik Kurumu. http://www.tuik.gov.tr/PreTablo.do?alt id=1059.

http://www.tuik.gov.tr/PreHaberBultenleri.do?id=24644

TÜIK (2016). Türkiye Sağlık Araştırması Raporu http://www.tuik.gov.tr/PreTablo.do?alt id=1095

Twigg J., Lovell E., Kett M. (2018). Disability inclusion and disaster risk reduction: Overcoming barriers to progress. http://repo.floodalliance.net/ispui/bitstream/44111/2861/1/odıdisability.jpg

UNISDR (2015). The Sendai framework for disaster risk reduction 2015-2030. United Nations Office for Disaster Risk Reduction, Geneva. Retrieved from http://www.preventionweb.net/files/43291 sendaiframeworkfordrren.pdf

UNISDR $\frac{\text { (2017). }}{2}$ Terminology on Disaster Risk Reduction, https://www.unisdr.org/we/inform/terminology

WB Disability Inclusion and Accountability Framework. https://blogs.worldbank.org/sustainablecities/leaving-no-one-behind-development-roadmapdisability-inclusion

Özürlüler Vakfı. Ulaşılabilirlik Kılavuzu, Mimari Projelerde Engelli ve Yaşılıarla İlgili Olarak Uyulması Gereken Temel Kurallar. http://www.ozurlulervakfi.org.tr/docs/ozurluler.vakfimimari.erisilebilirlik.kilavuzu.pdf; http://www.izmimod.org.tr/yasa/engelli.html

5378 Sayılı Engelliler Hakkında Kanun

657 Sayilı Devlet Memur Kanunu

3984 Sayılı Kanun

5216 Sayılı Kanun 